\title{
Oxidative stress-mediated caspase-dependent intrinsic apoptosis and proautophagic therapeutic potential of Salvia moorcroftiana Wall. ex Benth. growing in the Kashmir Valley, India
}

\author{
Aadil Khursheed $^{*(\mathbb{}}$, Vikrant Jain ${ }^{(\mathbb{0}}$
}

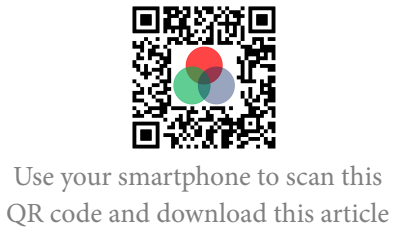

Department of Chemistry, Madhyanchal Professional University, Ratibad,

Bhopal-462044, M.P, India

\section{Correspondence}

Aadil Khursheed, Department of Chemistry, Madhyanchal Professional University, Ratibad, Bhopal-462044, M.P, India

Email: aaddikhan12@gmail.com

History

- Received: Oct 07, 2021

- Accepted: Nov 19, 2021

- Published: Nov 30, 2021

DOI : 10.15419/bmrat.v8i11.708

\section{Check for updates}

\section{Copyright}

( $)$ Biomedpress. This is an openaccess article distributed under the terms of the Creative Commons Attribution 4.0 International license.

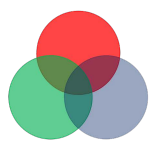

\begin{abstract}
Background: Salviamoorcroftiana Wall. ex Benth. is a herbaceous perennial plant indigenous to the Himalayan mountains and especially common in the Kashmir Valley, India. This plant was selected based on its ethnopharmacological promise and the dearth of scientific reporting on its biological activity. This study examined the anticancer therapeutic potential of Salviamoorcroftiana Wall. ex Benth. and also sought to demonstrate its induction of apoptosis, autophagy, and oxidative stress in lung and breast cancer cells. Methods: Soxhlet's extraction technique was used to obtain an ethanolic extract of Salviamoorcroftiana. A 3-(4,5-dimethylthiazol-2-yl)-2,5-diphenyltetrazolium bromide (MTT) assay was used to evaluate the effects of an ethanolic extract on cell proliferation, and acridine orange/ethidium bromide (AO/EB) staining was used to assess apoptotic cell morphology. Transmission electron microscopy was used to detect autophagy, and 2'-7'dichlorofluorescin diacetate (DCFH-DA) staining was used to measure oxidative stress. Apoptosis and autophagyrelated protein levels were assessed with western blotting. Results: The ethanolic extract showed concentration and time-dependent inhibition of proliferation against A549 and MDA-MB-231 cell lines with $\mathrm{IC}_{50}$ values of $129.32 \mu \mathrm{g} / \mathrm{ml}$ and $118.12 \mu \mathrm{g} / \mathrm{ml}$, respectively ${ }^{*} p<0.05$ ). The AO/EB staining revealed that ethanolic extract brings about apoptotic transformations in both cell lines, further supported by western blotting showing higher caspase 3 and 9 and Bax expression and lower $\mathrm{BCl}-2$ expression. TEM analysis and western blotting showed the formation of autophagosomes and higher expression of LC3B-I and LC3B-II in A549 and MDA-MB-231, respectively, confirming autophagy. Finally, the DCFH-DA staining showed concentration-reliant augmentation of intracellular ROS production in A549 and MDA-MB-231 cells, indicating the induction of oxidative stress by the ethanolic extract. Conclusion: This study showed the remarkable anticancer activity of an ethanolic extract of Salvia moorcroftiana Wall. ex Benth. roots via apoptosis, autophagy, and oxidative stress. Natural drug discovery and design against lung and breast cancer could benefit from these findings.
\end{abstract}

Key words: Apoptosis, autophagy, cancer, caspase, oxidative stress, Salvia moorcroftiana wall. ex Benth.

\section{INTRODUCTION}

Cancer is the most dangerous health condition mankind faces and currently predominates over other health conditions in mortality and global occurrence $^{1}$. Lung and breast cancer are now becoming common. In the United States, lung cancer is ranked second-most-frequent and is one of the foremost causes of cancer-related death ${ }^{2}$. More than 0.25 million cases of lung cancer were expected in the U.S. in 116,930 women and 130,340 men $^{3}$. Previous studies have cited lung cancer as the leading cause of cancer-related deaths in men over 40 years and women over 60 years of age, more than prostate cancer, breast cancer, and leukemia. However, recent years have seen a gradual decrease in lung cancer incidence and mortality because of enhanced tools and mass awareness of screening for the disease. The main risk factor for lung cancer is tobacco consumption via smoking ${ }^{4}$. The decline in tobacco consumption has reduced the incidence of lung cancer by $48 \%$ among men and 23\% among women. Secondhand smoke is another leading risk factor contributing to this fatal disease $^{5,6}$. These statistics indicate a pressing need for drugs or chemotherapeutics with efficient action against lung cancer.

Breast cancer is another form of harmful neoplasm mostly found in women. Breast cancer is metastatic and invades distant sites, harming other parts of the body as well ${ }^{7}$. Each year, about 1 million cases of breast cancer are recorded worldwide ${ }^{8}$. In the United States, breast cancer is the most frequent cancer diagnosed in women, with an incidence rate of $12.5 \%$. 
The lethality of this illness can be seen in the high incidence of death among patients, 1 in 35 women diagnosed ${ }^{9}$. Hormone therapy and immune therapies have proven fruitful in eliminating this fatal disease. However, disease recurrence and low survival rates still make this disease a notable challenge to humanity ${ }^{10}$. The high incidence and death rates of this fatal disease indicate the need for novel management therapies and therapeutics that could eliminate the disease, stop recurrence, and improve survival.

Both lung and breast cancer are lethal health conditions associated with enormous mortality and morbidity globally. Recent advancements in cancer treatment have eased the global cancer burden somewhat, but lung and breast cancers remain hazards that must be addressed by scientists and researchers. Considering the immediate demand for novel treatment options, this study was designed to evaluate the anticancer effects of an ethanolic extract of Salvia moorcroftiana wall. ex Benth. roots. Moreover, the underlying action mechanism was also studied by analyzing apoptosis, autophagy, and oxidative stress.

The Salvia genus belongs to the family Lamiaceae and comprises more than 900 species ${ }^{11}$. This genus is distributed throughout the world and the most suitable growing conditions are temperate and tropical regions ${ }^{12}$. Salvia species are important in traditional medicines used worldwide, showing anticancer, antidiabetic, antioxidant, and antibacterial activities ${ }^{13-16}$. Salviamoorcroftiana wall. ex Benth. is commonly known as "kallijari" and is native to the Kashmir Valley in the Himalayas. The perennial plant is herbaceous and grows up to $90 \mathrm{~cm}$, with sturdy stems. The roots and seeds are used to treat cough and hemorrhoids and are also used as an emetic. The leaves are used to treat boils and as medicine for itching and guinea worm ${ }^{17}$. The roots show rich phytochemistry and bioactive phytochemicals ${ }^{18}$. Despite their rich phytochemistry, very little is known about the pharmacological and medicinal activities of Salviamoorcroftiana wall. ex Benth. roots. This study could help determine the anticancer potential of an ethanolic extract of Salvia moorcroftiana wall. ex Benth. roots against lung and breast cancer cells.

\section{METHODS}

\section{Chemicals and reagents}

RMPI-1640 medium and dichlorodihydrofluorescein diacetate (DCFH-DA) were obtained from Thermo Fisher Scientific, Inc., Waltham, MA, United States. Dimethyl sulphoxide (DMSO), 10\% fetal bovine serum, penicillin, streptomycin, 3-(4,5dimethylthiazol-2-yl)-2,5-diphenyl tetrazolium bromide (MTT), acridine orange/ethidium bromide
(AO/EB), phosphate buffer saline (PBS), glutaraldehyde, ethanol, osmium tetroxide, acetone, uranyl acetate, lead citrate, and RIPA lysis buffer were obtained from Sigma-Aldrich; Merck KGaA, Darmstadt, Germany.

\section{Plant material}

Salvia moorcroftiana Wall. ex Benth. plant material was collected from hilly areas of District Budgam, Jammu and Kashmir on June 20, 2020. The plant was identified and characterized by Dr. Kanchan Yadav, Department of Botany, Madhyanchal Professional University, Ratibad, Bhopal, Madhya Pradesh; a sample was deposited with her under voucher no. MPU-B-107. The roots of the plant were carefully removed, washed under tap water, and shade dried at $30-33{ }^{\circ} \mathrm{C}$ for three weeks. The dried roots were powdered with a mortar and pestle. To maintain the quality of the extract, all the dirt and moisture were eliminated. The powder was stored in air-tight plastic bags until extraction.

\section{Ethanolic extraction}

The $200 \mathrm{~g}$ of powdered, shade-dried Salviamoorcroftiana Wall. ex Benth. roots were extracted with boiling $\left(79^{\circ} \mathrm{C}\right)$ ethanol for $24 \mathrm{~h}$ using Soxhlet's apparatus. The crude extract was concentrated and leftover moisture was eliminated under reduced pressure with a rotatory evaporator. The extract was then stored at $4{ }^{\circ} \mathrm{C}$ in a refrigerator. The refrigeration preserved the quality of the extract for future use. Ethanolic extracts of Salvia moorcroftiana Wall. ex Benth. roots were prepared at $12.5,25,50$, 100,200 , and $400 \mu \mathrm{g} / \mathrm{ml}$ with $0.05 \%$ of dimethyl sulphoxide (DMSO) for anticancer analysis.

\section{Cell culture and conditions}

The A549 lung cancer cells and MDA-MB-231 breast cancer cells were procured from the National Center for Cell Sciences, Pune, Maharashtra. Both cell lines were maintained in RMPI-1640 medium containing $10 \%$ fetal bovine serum, penicillin, and streptomycin. The cell cultures were preserved in a humid environment at $37^{\circ} \mathrm{C}$ with $5 \% \mathrm{CO}_{2}$.

\section{MTT assay}

The MTT was conducted to evaluate the antiproliferative effects of the ethanolic extract of Salvia moorcroftiana Wall. ex Benth. roots against A549 lung and MDA-MB-231 breast cancer cell lines. The A549 and MDA-MB-231 cells were seeded to individual 96well plates, maintaining a density of $1 \times 10^{5}$ cells/well. 
The cultured cell lines were divided into experimental groups, each of which received a different concentration of the ethanolic extract: $0,12.5,25,50,100$, 200 , and $400 \mu \mathrm{g} / \mathrm{ml}$. These treated cell lines were incubated for $24 \mathrm{~h}, 48 \mathrm{~h}$, and $72 \mathrm{~h}$ at $37^{\circ} \mathrm{C}$. After the incubation time, each experimental group received 100 $\mu \mathrm{l}$ of MTT reagent $(5 \mu \mathrm{g} / \mathrm{ml})$ followed by $4 \mathrm{~h}$ additional incubation. The formazan crystals formed by the MTT with living cells were dissolved in DMSO and subjected to colorimetric analysis. The optical density of each experimental group was determined by recording the absorbance at $490 \mathrm{~nm}$ with a microplate reader. The procedures for each experimental group were performed in triplicate.

\section{AO/EB staining assay}

The morphological characteristics of ethanolic extract-treated A549 and MDA-MB-231 cells were monitored by $\mathrm{AO} / \mathrm{EB}$ staining with fluorescence microscopy. The A549 and MDA-MB-231 cells were seeded in 24 -well plates at a density of $1 \times 10^{4}$ cells/well for $12 \mathrm{~h}$. The cells were divided into experimental groups, each of which received a different concentration of the ethanolic extract: $0,50,100$, and $200 \mu \mathrm{g} / \mathrm{ml}$, followed by $24 \mathrm{~h}$ of incubation at $37^{\circ} \mathrm{C}$. Afterward, the treated cells were washed twice in PBS and then stained with $20 \mu \mathrm{l} \mathrm{AO/EB}$ staining solution. The stained cells were incubated without light for 15 min. Finally, the morphological and apoptosis characteristics of the treated A549 and MDA-MB-231 cells were assessed under a fluorescent microscope (Nikon Corporation., Tokyo, Japan).

\section{Transmission electron microscopy (TEM)}

The autophagy-promoting effects of the ethanolic extract of Salvia moorcroftiana Wall. ex Benth. roots in A549 lung and MDA-MB-231 breast cancer cells were evaluated with TEM analysis. The cell lines were loaded in individual 24-well plates at a concentration of $1 \times 10^{4}$ cells/well and cultured for 24 h. The cultures were then divided into experimental groups and received either 0 or $100 \mu \mathrm{g} / \mathrm{ml}$ of the extract. Afterward, the cells were incubated for $24 \mathrm{~h}$ and then washed and fixed with PBS and glutaraldehyde (2.5\%). The washed cells were then stained with $2 \%$ osmium tetroxide and subsequently incubated for 2 $\mathrm{h}$ at room temperature. The treated and stained A549 and MDA-MB-231 cells were dehydrated with ethanol and then immersed in pure acetone. Before sectioning $(5-7 \mu \mathrm{m})$ under the Ultracut E ultra-thin slicer, the cells were placed in an epoxy resin mixture. The ultrathin sections were stained with lead citrate and uranyl acetate (3\%) and then incubated for $20 \mathrm{~min}$ without light at room temperature. Finally, the ultrathin stained sections were washed twice in distilled water and subsequently loaded into a transmission electron microscope (Philips Medical Systems, Eindhoven, Netherland).

\section{Reactive oxygen species assessment}

The ROS production in treated and control A549 and MDA-MB-231 cells was measured with a DCFH-DA staining assay. The A549 and MDA-MB-231 cells were plated in 24-well plates at a density of $1 \times 10^{4}$ cells/well for $12 \mathrm{~h}$. The cells were divided into experimental groups, each of which received a different concentration of the ethanolic extract: $0,50,100$, and $200 \mu \mathrm{g} / \mathrm{ml}$, followed by $24 \mathrm{~h}$ of incubation at 37 ${ }^{o} \mathrm{C}$. Afterward, the cells were incubated with $10 \mathrm{mM}$ of DCFH-DA at $37{ }^{\circ} \mathrm{C}$ for $25 \mathrm{~min}$. In the presence of intracellular ROS, non-fluorescent DCFH oxidizes to fluorescent DCF. This change was detected by taking absorbance measurements with a fluorescent microplate reader at $570 \mathrm{~nm}$.

\section{Western blotting}

The expression of apoptosis and autophagy-related proteins in A549 and MDA-MB-231 cells treated with an ethanolic extract of Salvia moorcroftiana Wall. ex Benth. roots was monitored with western blotting. The A549 and MDA-MB-231 cells were treated with different concentrations of the ethanolic extract $(0$, 50, 100, and $200 \mu \mathrm{g} / \mathrm{ml}$ ) for $24 \mathrm{~h}$. The treated cells were lysed with RIPA lysis buffer. The protein content within each lysate of A549 and MDA-MB-231 cells was measured through a bicinchoninic acid assay. From each sample, about $40 \mu \mathrm{g}$ of proteins were separated with 10-15\% SDS-PAGE and transferred to nitrocellulose membranes blocked with skim milk (5\%) for $1 \mathrm{~h}$ at room temperature. These membranes were incubated overnight at $4{ }^{\circ} \mathrm{C}$ with primary antibodies for caspase-3, caspase-9, Bax, Bcl-2, LC3B-I, and LC3B-II (1:500 dilutions; ThermoFisher Scientific). After primary antibody treatment, the membranes were exposed to HRP conjugated goat antirabbit secondary antibodies (1:2,000 dilutions; OriGene Technologies, Inc., Beijing, China) for $1 \mathrm{~h}$ without light at $37^{\circ} \mathrm{C}$. Finally, the protein bands were developed with an ECL substrate spray and pictured with the Chemidoc XRS system (Bio-Rad Laboratories, Inc., Hercules, CA, United States).

\section{Statistical analysis}

The experimental data of the three triplicate experiments are represented as mean $\pm \mathrm{SD}$. The differences 
among groups were analyzed with a one-way ANOVA followed by Tukey's test using GraphPad Prism software version 5.0 (GraphPad Software, Inc., La Jolla, CA, United States). A* $p<0.05$ was considered statistically significant.

\section{RESULTS}

\section{Proliferation inhibition by Salvia moorcrof- tiana Wall. ex Benth. root extract}

The proliferation of A549 and MDA-MB-231 cells was assessed with an MTT assay after treatment with ethanolic extract of Salvia moorcroftiana Wall. ex Benth. roots. The ethanolic extract inhibited the proliferation of A549 cells significantly $(p<0.05)$. The proliferation inhibition was not only concentrationdependent but time-dependent as well (Figure 1). The proliferation of A549 cells reduced significantly from $100 \%$ in controls to almost $23 \%, 14 \%$, and $7 \%$ at $400 \mu \mathrm{g} / \mathrm{ml}$ after $24 \mathrm{~h}, 48 \mathrm{~h}$, and $72 \mathrm{~h}$, respectively. Similar results were observed in the MDA-MB-231 cells, where the cell proliferation was significantly reduced with increasing extract concentration and exposure time. The proliferation reduced from $98 \%$ in controls to $18 \%, 12 \%$, and $9 \%$ at $400 \mu \mathrm{g} / \mathrm{ml}$ after $24 \mathrm{~h}, 48 \mathrm{~h}$, and $72 \mathrm{~h}$, respectively (Figure 2). The ethanolic extract of Salvia moorcroftiana Wall. ex Benth. roots showed an efficient $\mathrm{IC}_{50}$ concentration of $118.12 \mu \mathrm{g} / \mathrm{ml}$ against MDA-MB-231 cells and $129.32 \mu \mathrm{g} / \mathrm{ml}$ against A549 cells.

Apoptosis induction by Salvia moorcroftiana Wall. ex Benth. root extract

Apoptosis in A549 and MDA-MB-231 cells treated with an ethanolic extract of Salviamoorcroftiana Wall. ex Benth. roots was investigated with $\mathrm{AO} / \mathrm{EB}$ staining and western blotting. The treated A549 cells showed characteristic apoptotic features such as membrane damage, membrane blebbing, formation of apoptotic bodies, nuclear disintegration, DNA damage, and loss of cell integration (Figure 3). The control group showed no such alterations and the overall cell morphology remained normal. The treated MDAMB-231 cells showed similar morphological changes under fluorescence microscopy. The cell destructive effects of the ethanolic extract were enhanced with increased concentration $(0-200 \mu \mathrm{g} / \mathrm{ml})$. The morphological changes observed after extract treatment are hallmarks of apoptosis and therefore indicate the proapoptotic proliferation inhibition of A549 cells. The proapoptotic antiproliferative effects of the ethanolic extract were further confirmed at the molecular level by evaluating the expression of apoptosisrelated proteins in both the A549 and MDA-MB231 cancer cell lines. The expression of caspase-3, caspase- 9 , and Bax proapoptotic proteins notably increased with increasing concentrations of ethanolic extract in both target cell lines (Figure 4). Simultaneously, the expression of Bcl-2 antiapoptotic protein decreased dramatically in treated cells compared with the controls. These results suggest that the antiproliferative effects of an ethanolic extract of Salvia moorcroftiana Wall. ex Benth. roots induce apoptosis in both A549 and MDA-MB-231 cells.

\section{Autophagy induction by Salvia moorcrof- tiana Wall. ex Benth. root extract}

Autophagy in A549 and MDA-MB-231 cells treated with an ethanolic extract of Salvia moorcroftiana Wall. ex Benth. roots was monitored with TEM analysis and western blotting. The treated A549 cells showed the formation of autophagosomes under TEM (Figure 5 A). Autophagosomes are hallmarks of autophagic cell death. Autophagy in A549 cells was further confirmed when higher expressions of pro-autophagy proteins LC3B-I and LC3B-II were recorded in treated cells compared with control cells. Similarly, autophagosomes and higher expressions of LC3B-I and LC3B-II were detected in treated MDA-MB-231 cells (Figure 5 B). These results suggest that the ethanolic extract of Salvia moorcroftiana Wall. ex Benth. roots stimulates autophagy in both A549 and MDA-MB231 cells.

\section{Oxidative stress induced by Salvia moor- croftiana Wall. ex Benth. root extract}

The induction of oxidative stress in A549 and MDA-MB-231 cells with an ethanolic extract of Salviamoorcroftiana Wall. ex Benth. roots was assessed with DCFH-DA staining. The results indicate that ROS production in A549 cells was dramatically enhanced after exposure to the ethanolic extract. ROS production increased from $11 \%$ in controls to $27 \%$, $45 \%, 65 \%$, and $85 \%$ at $12.5,50,100$, and $200 \mu \mathrm{g} / \mathrm{ml}$ of ethanolic extract, respectively (Figure 6). Similar results were demonstrated in the MDA-MB-231 cells, where the ROS production increased from $7 \%$ to $73 \%$ with increasing concentrations $(0-200 \mu \mathrm{g} / \mathrm{ml})$ of ethanolic extract (Figure 7). Therefore, the results from DCFH-DA staining indicated that the ethanolic extract of Salvia moorcroftiana Wall. ex Benth. roots induced oxidative stress in both A549 and MDA-MB231 cells. 


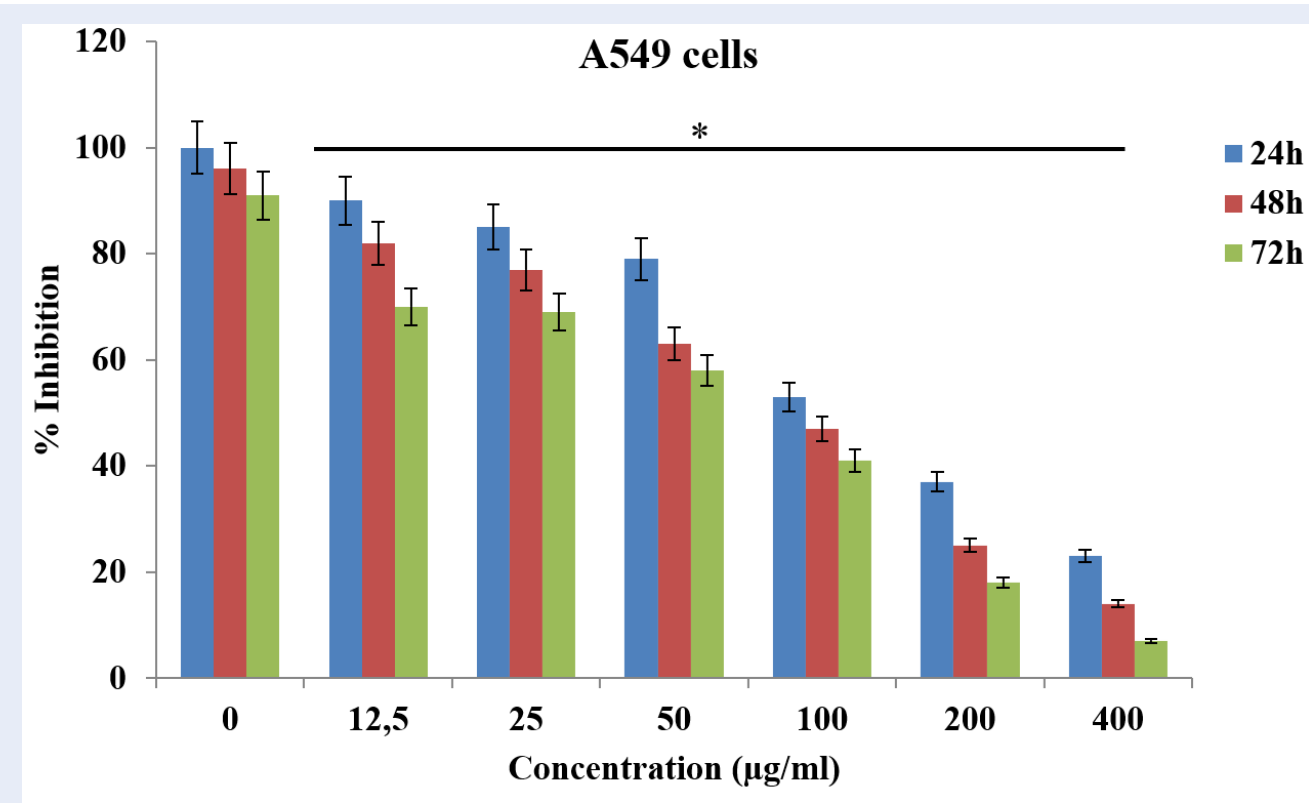

Figure 1: The proliferation inhibition of $A 549$ cells after $24 \mathrm{~h}, 48 \mathrm{~h}$ and $72 \mathrm{~h}$ exposure to indicated concentrations of ethanolic extract of Salvia moorcroftiana Wall. ex Benth. roots. Results showed significant inhibition of A549 cell proliferation. The experimental data of three individual triplicate experiments are represented as mean \pm SD. ${ }^{*} p<0.05$. https://doi.org/10.6084/m9.figshare.17105051.v1

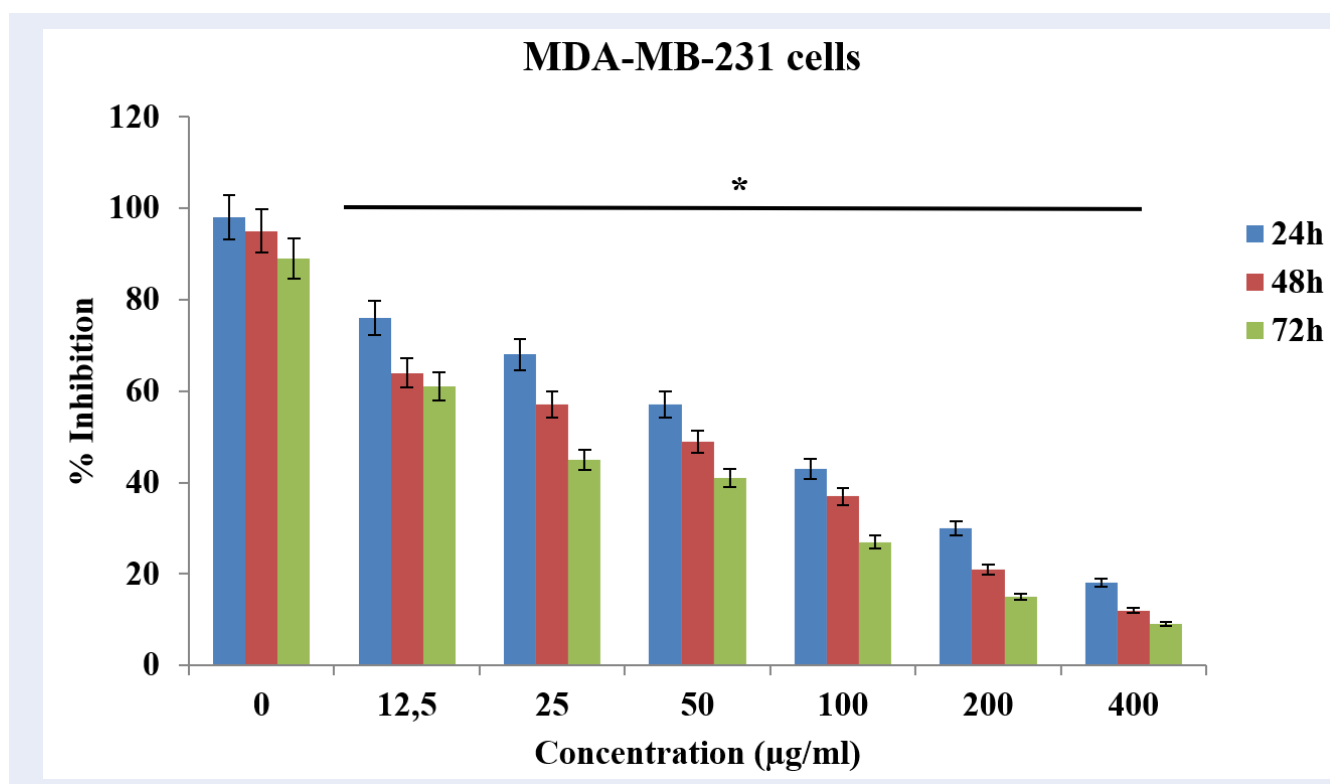

Figure 2: The proliferation inhibition of MDA-MB-231 cells after $24 \mathrm{~h}, 48 \mathrm{~h}$ and $72 \mathrm{~h}$ exposure to indicated concentrations of ethanolic extract of Salvia moorcroftiana Wall. ex Benth. roots. Results showed significant inhibition of MDA-MB-231 cell proliferation. The experimental data of three individual triplicate experiments are represented as mean $\pm S D$. ${ }^{*} p<0.05$. https://doi.org/10.6084/m9.figshare.17105063.v1 

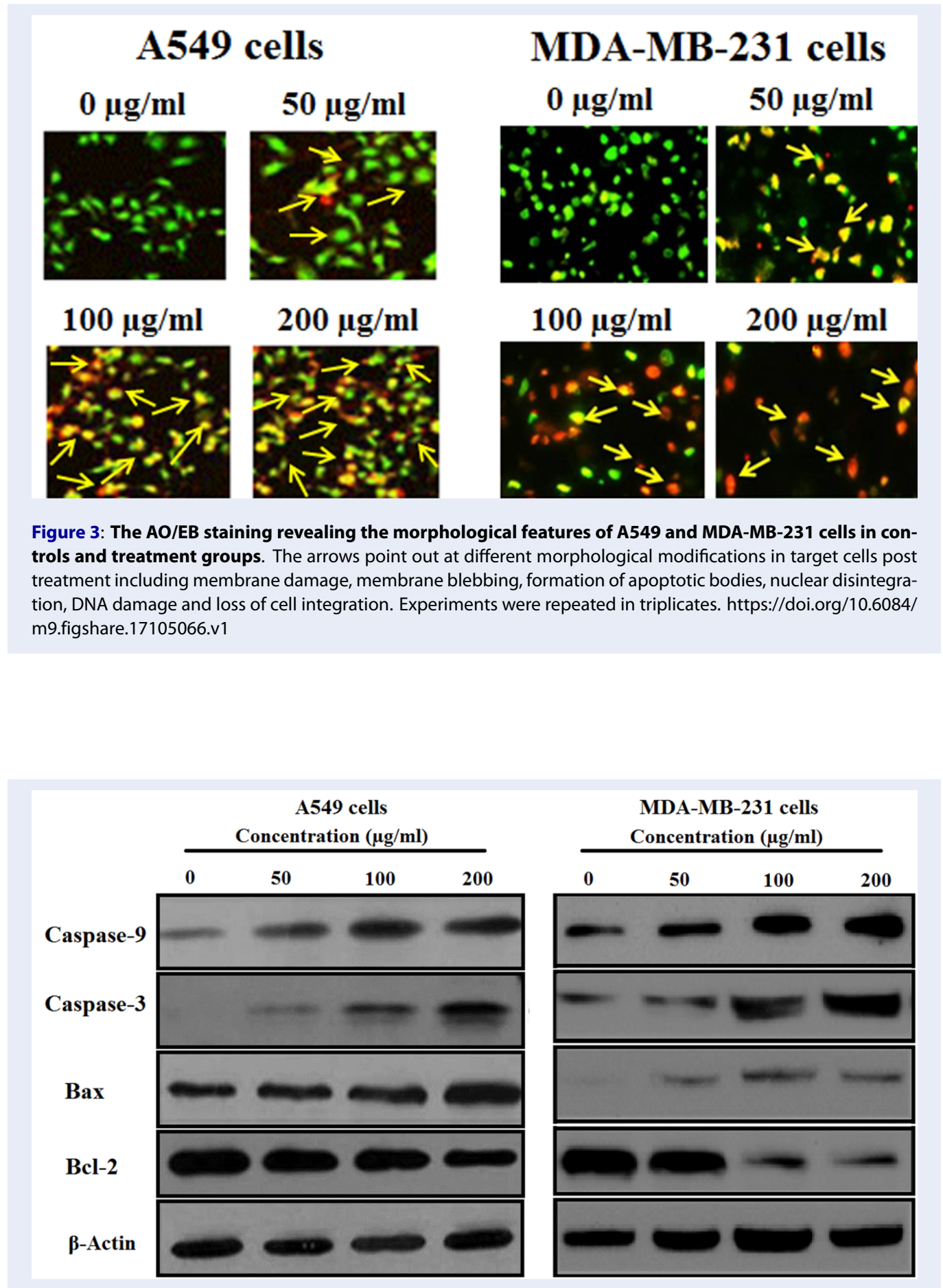

Figure 4: Western blotting analysis. The western blotting analysis representing the expression of apoptosis allied proteins in A549 and MDA-MB-231 cells post ethanolic extract treatment. The results showed that post extract treatment at different concentrations, the expressions of Caspase-3, Caspase- 9 and Bax proteins increased significantly, while the expressions of Bcl-2 lowered significantly. https://doi.org/10.6084/m9.figshare.17105072. v1 
A

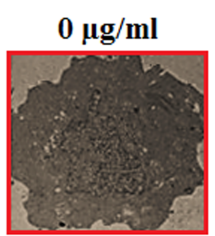

B

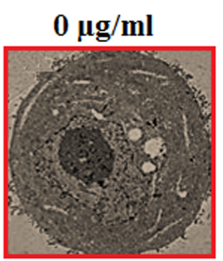

$100 \mu \mathrm{g} / \mathrm{ml}$

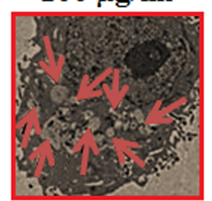

A549 cells

\section{Concentration $(\mu \mathrm{g} / \mathrm{ml})$}

LC3B-I

LC3B-II

$\begin{array}{llll}0 & 50 & 100 & 200\end{array}$

$\beta$-Actin

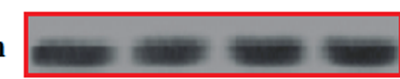

\section{MDA-MB-231 cells}

$100 \mu \mathrm{g} / \mathrm{ml}$

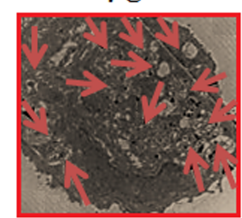

Concentration $(\mu \mathrm{g} / \mathrm{ml})$

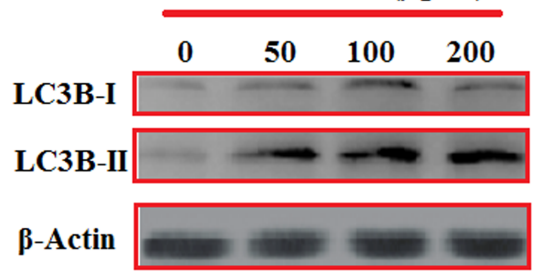

Figure 5: A) Images of transmission electron microscope revealing formation of autophagosomes (indicated by arrows) in treated cells compared to controls and western blots showing expressions of autophagy allied proteins in A549 cells. B) Images of transmission electron microscope revealing formation of autophagosomes (indicated by arrows) in treated cells compared to controls and western blots showing expressions of autophagy allied proteins in MDA-MB-231 cells. https://doi.org/10.6084/m9.figshare.17105087.v1

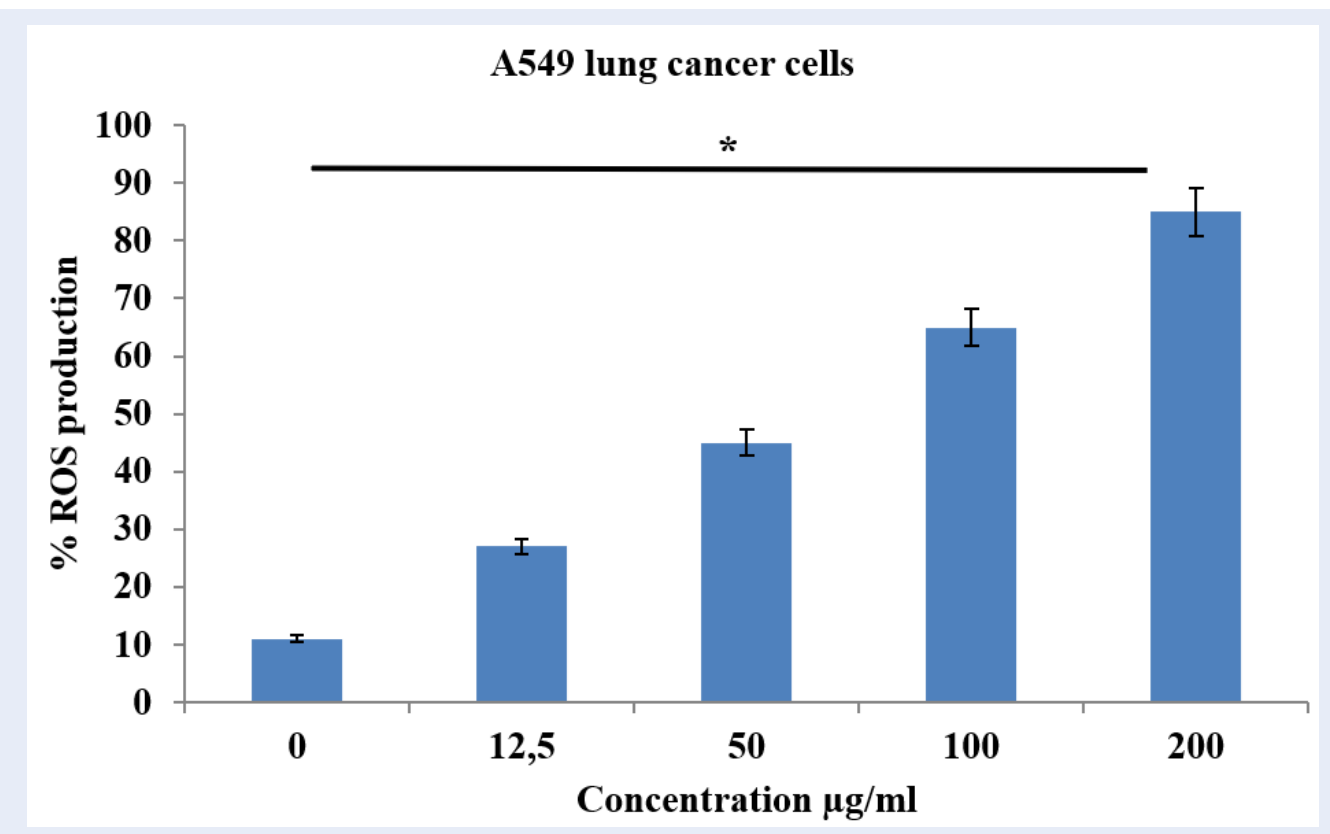

Figure 6: The percentage ROS production in ethanolic extract of Salvia moorcroftiana Wall. ex Benth.roots treated A549 cells with the help of DCFH-DA fluorescence staining. The experimental data of three individual triplicate experiments are represented as mean \pm SD. ${ }^{*} p<0.05$. https://doi.org/10.6084/m9.figshare.17105096.v 1 


\section{MDA-MB-231 breast cancer cells}

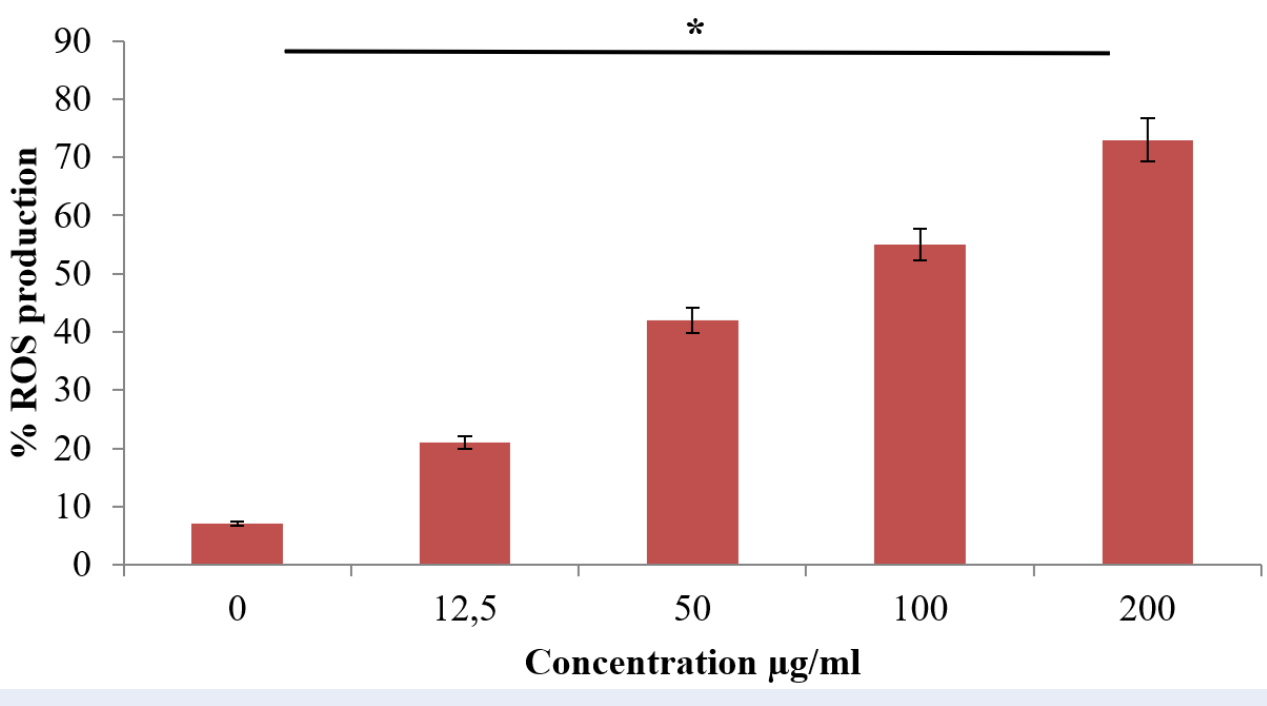

Figure 7: The percentage ROS production in ethanolic extract of Salvia moorcroftiana Wall. ex Benth. roots treated MDA-MB-231 cells with the help of DCFH-DA fluorescence staining. The experimental data of three individual triplicate experiments are represented as mean \pm SD. ${ }^{*} p<0.05$. https://doi.org/10.6084/m9.figshare.1 7105102.v1

\section{DISCUSSION}

Medicinal plants are the major source of drugs in the present-day pharmaceutical industry. Due to enormous diversity in the occurrence and structural variety of their phytochemical constituents, medicinal plants have been a source of drug discovery and design since antiquity ${ }^{19}$. The bioactive phytochemicals identified and isolated from medicinal plants are extensively screened for drugs to treat different human disorders. This led to the discovery of taxol, paclitaxel, vincristine, and vinblastine, natural products that have been incorporated into chemotherapy ${ }^{20}$. Medicinal plants have been actively used in the pharmaceutical industry.

Salvia species are among the most prevalent medicinal plants with a wide range of therapeutic potential. This genus is a part of Traditional Chinese Medicine, Ayurveda, and other folk medicines worldwide ${ }^{21}$. Moreover, Salvia species have been the source of numerous bioactive molecules, including cryptotanshinone, castanol C, camphor, and dihydrotanshinone ${ }^{22}$. Moreover, Salvia species show tremendous anticancer potential against a wide range of human cancers, including prostate, breast, liver, and lung ${ }^{23}$. Therefore, this study was designed to investigate the anticancer potential of ethanolic extracts of Salvia moorcroftiana Wall. ex Benth. roots and determine its possible mechanism of action by studying apoptosis, autophagy, and oxidative stress in A549 lung and MDA-MB-231 breast cancer cells. The results showed promising antiproliferative effects following a doseand time-reliant pattern. These results were similar to those of previous studies reporting the antiproliferative effects of Salvia species.

Apoptosis is a natural phenomenon and the proactive form of natural cell death is often termed PCD$\mathrm{I}^{24}$. Apoptosis is a stepwise process to eliminate damaged, malfunctioning, and cancerous cells to maintain the optimum homeostasis of cells and tissues. Suppression of apoptosis often leads to the pathogenesis of malignant disorders in humans, including cancer. The Bcl-2 family of proteins regulates apoptosis, incorporating both pro-apoptotic (Bax and Bad) and antiapoptotic (Bcl-2) proteins ${ }^{25}$. Caspases initiate the apoptosis process by regulating the loss of mitochondrial membrane potential and the release of cytochrome $c$ into the cytoplasm, initiating a reaction cascade that ultimately generates apoptosomes or apoptotic bodies ${ }^{26}$. Triggering apoptosis in cancer cells has become a popular topic for research nowadays because of its natural instigation and selective degradation. Bringing about apoptosis in cancer cells could eliminate the disease at its root. Medicinal plants, including Salvia species, have previously been reported as inducing apoptosis in different human 
cancer cell lines ${ }^{27,28}$. Salvia moorcroftiana tends to upregulate proapoptotic proteins and downregulate antiapoptotic proteins. This study, for the first time, evaluates the proapoptotic effects of an ethanolic extract of Salviamoorcroftiana Wall. ex Benth. roots. We observed that, consistent with previous findings, the ethanolic extract of Salvia moorcroftiana Wall. ex Benth. roots showed proapoptotic effects by inducing nuclear damage, inhibiting $\mathrm{Bcl}-2$, and upregulating caspases and Bax proteins in A549 and MDA-MB231 cells.

Autophagy is another pivotal survival mechanism that operates based on starvation and stress ${ }^{29}$. Autophagy is often termed PCD-II and is operated by several factors. The formation of autophagosomes indicates the onset of autophagy. During starvation or fasting, the body's demand for nutrients and energy increases drastically. This is addressed by activating autophagy ${ }^{30}$. However, this is a self-destructive process in which the body eats its own damaged, malfunctioning, and cancerous cells to manage its nutrient demands during starvation. Established chemotherapeutics target cancer cells, inhibiting the disease by stimulating the autophagy of malignant cells. Many medicinal plants, including Salvia species, have been reported to induce autophagic cell death in cancer cells, but no such evidence had been reported for Salviamoorcroftiana Wall. ex Benth. roots ${ }^{31}$. This study, for the first time, evaluated the proautophagic potential of an ethanolic extract of Salvia moorcroftiana Wall. ex Benth. roots and found that it induced autophagy in A549 and MDA-MB-231 cells, a finding that was further supported by the overexpression of LC3B-I and LC3B-II.

Oxidative stress is induced by the overproduction of ROS in cells. ROS generation is often associated with damage to genetic material and the pathogenesis of several malignant disorders, including cancer $^{32}$. ROS are likely to react with almost everything they interact with and often disturb normal cellular processes. Thus, ROS are dangerous to normal cells but can stimulate cell death mechanisms such as autophagy and apoptosis in cancer cells ${ }^{33}$. This study evaluated the ROS production in A549 and MDAMB-231 cells after treatment with ethanolic extract and found promising results. The extract induced concentration-reliant oxidative stress in both target cell lines.

\section{CONCLUSIONS}

In conclusion, this study's findings revealed that ethanolic extracts of Salvia moorcroftiana Wall. ex
Benth. roots possess remarkable anticancer potency against the A549 lung and MDA-MB-231 breast cancer cell lines. Furthermore, the ethanolic extract induced apoptosis, autophagy, and oxidative stress in A549 and MDA-MB-231 cells. Therefore, our study offers a foundation for identifying and isolating bioactive entities in the extract that can contribute to lung and breast cancer research and treatment.

\section{ABBREVIATIONS}

AO/EB: Acridine Orange/Ethidium Bromide

Bad: Bcl-2 associated agonist of cell death

Bax: Bcl-2-associated X protein

Bcl-2: B-cell lymphoma 2

DCFH-DA: Dichloro-dihydro-fluorescein diacetate

PCD: Programmed Cell Death

ROS: Reactive oxygen species

TEM: Transmission electron microscopy

\section{ACKNOWLEDGMENTS}

Authors are highly thankful to the Department of Pharmacy and Department of Chemistry at Madhyanchal Professional University, Ratibad, Bhopal462044, M.P, INDIA, for providing academic support and necessary equipment's.

\section{AUTHOR'S CONTRIBUTIONS}

All the authors contributed equally in designing, execution, data interpretation and writing of this research work. All authors read and approved the final manuscript.

\section{FUNDING}

None.

\section{AVAILABILITY OF DATA AND MATERIALS}

Data and materials used and/or analyzed during the current study are available from the corresponding author on reasonable request.

\section{ETHICS APPROVAL AND CONSENT TO PARTICIPATE}

Not applicable.

\section{CONSENT FOR PUBLICATION}

Not applicable.

\section{COMPETING INTERESTS}

The authors declare that they have no competing interests. 


\section{REFERENCES}

1. Fitzmaurice C, Dicker D, Pain A, Hamavid H, Moradi-Lakeh M, Maclntyre MF, et al. The global burden of cancer 2013. JAMA Oncology. 2015;1(4):505-27. PMID: 26181261. Available from: 10.1001/jamaoncol.2015.0735.

2. Alexander M, Kim SY, Cheng H. Update 2020: Management of Non-Small Cell Lung Cancer. Lung. 2020;198(6):897-907. PMID: 33175991. Available from: 10.1007/s00408-020-004075.

3. Siegel RL, Miller KD, Jemal A. Cancer statistics, 2020. CA: a Cancer Journal for Clinicians. 2020;70(1):7-30. PMID: 31912902. Available from: 10.3322/caac.21590.

4. Jeon J, Holford TR, Levy DT, Feuer EJ, Cao P, Tam J. Smoking and lung cancer mortality in the United States from 2015 to 2065: a comparative modeling approach. Annals of Internal Medicine. 2018;169(10):684-93. PMID: 30304504. Available from: $10.7326 / \mathrm{M} 18-1250$.

5. Couraud S, Zalcman G, Milleron B, Morin F, Souquet PJ. Lung cancer in never smokers: review. European Journal of Cancer (Oxford, England). 2012;48(9):1299-311. PMID: 22464348. Available from: 10.1016/j.ejca.2012.03.007.

6. Kim AS, Ko HJ, Kwon JH, Lee JM. Exposure to secondhand smoke and risk of cancer in never smokers: a meta-analysis of epidemiologic studies. International Journal of Environmental Research and Public Health. 2018;15(9):1981. PMID: 30208628. Available from: 10.3390/ijerph15091981.

7. Scully OJ, Bay BH, Yip G, Yu Y. Breast cancer metastasis. Cancer Genomics \& Proteomics. 2012;9(5):311-20. PMID: 22990110

8. McPherson K, Steel CM, Dixon JM. ABC of breast diseases. Breast cancer-epidemiology, risk factors, and genetics. BMJ (Clinical Research Ed). 2000;321(7261):624-8. PMID: 10977847. Available from: 10.1136/bmj.321.7261.624.

9. Lynch HT, Watson P, Conway TA, Lynch JF. Clinical/genetic features in hereditary breast cancer. Breast Cancer Research and Treatment. 1990;15(2):63-71. PMID: 2322650. Available from: 10.1007/BF01810778.

10. Bombonati A, Sgroi DC. The molecular pathology of breast cancer progression. The Journal of Pathology. 2011;223(2):307-17. PMID: 21125683. Available from: 10. 1002/path.2808.

11. Walker JB, Sytsma KJ, Treutlein J, Wink M. Salvia (Lamiaceae) is not monophyletic: implications for the systematics, radiation, and ecological specializations of Salvia and tribe Mentheae. American Journal of Botany. 2004;91(7):1115-25. PMID: 21653467. Available from: 10.3732/ajb.91.7.1115.

12. Min-hui L, Jian-min C, Yong P, Pei-gen X. Distribution of phenolic acids in Chinese Salvia plants. Wood Science and Technology. 2008;10(5):46-52.

13. Privitera G, Luca T, Castorina S, Passanisi R, Ruberto G, Napoli E. Anticancer activity of Salvia officinalis essential oil and its principal constituents against hormone-dependent tumour cells. Asian Pacific Journal of Tropical Biomedicine. 2019;9(1):24. Available from: 10.4103/2221-1691.250266

14. Vergine M, Nicoli F, Negro C, Luvisi A, Nutricati E, Accogli RA, et al. Phytochemical profiles and antioxidant activity of Salvia species from Southern Italy. Records of Natural Products. 2019;13(3):215. Available from: 10.25135/rnp.96.18.07.119.

15. Mahdizadeh R, Moein S, Soltani N, Malekzadeh K, Mahmoodreza M. Study the molecular mechanism of salvia species in prevention of diabete. International Journal of Pharmaceutical Sciences And Research. 2018;9(11):4512-21.

16. Delamare AP, Moschen-Pistorello IT, Artico L, Atti-Serafini L, Echeverrigaray S. Antibacterial activity of the essential oils of Salvia officinalis L. and Salvia triloba L. cultivated in South Brazil. Food Chemistry. 2007;100(2):603-8. Available from: 10.1016/j.foodchem.2005.09.078.

17. Rather MA, Dar BA, Bhat KA, Shawl AS, Qurishi MA, Dar MY. Mono-sesquiterpenoid composition in the leaves and flowers of Salvia moorcroftiana Wall ex Benth. growing wild in Kashmir, India. The Journal of Essential Oil Research. 2011;23(4):21-5. Available from: 10.1080/10412905.2011. 9700464 .

18. Kabouche A, Boutaghane N, Kabouche Z, Seguin E, Tillequin $F$, Benlabed K. Components and antibacterial activity of the roots of Salvia jaminiana. Fitoterapia. 2005;76(5):450-2. PMID: 15893885. Available from: 10.1016/j.fitote.2005.03.011.

19. Khan T, Ali M, Khan A, Nisar P, Jan SA, Afridi S. Anticancer plants: A review of the active phytochemicals, applications in animal models, and regulatory aspects. Biomolecules. 2019;10(1):47. PMID: 31892257. Available from: 10.3390/ biom 10010047 .

20. Gezici S, Sekeroglu N. Current Perspectives in the Application of Medicinal Plants Against Cancer: Novel Therapeutic Agents . Anticancer Agents Med Chem. 2019;19(1):101-111. PMID: 30582485. Available from: $10.2174 / 1871520619666181224121004$

21. Fan TP, Zhu Y, Leon C, Franz G, Bender A, Zheng X. Traditional Chinese Medicine Herbal Drugs: From Heritage to Future Developments. In The Science and Regulations of Naturally Derived Complex Drugs. Cham: Springer; 2019. Available from: 10.1007/978-3-030-11751-1_4.

22. Jiang $Y$, Zhang L, Rupasinghe HV. The anticancer properties of phytochemical extracts from Salvia plants. Botanics : Targets and Therapy. 2016;6:25-44.

23. Hao DC, Ge GB, Xiao PG. Anticancer drug targets of Salvia phytometabolites: chemistry, Biology and omics. Current Drug Targets. 2018;19(1):1-20. PMID: 27924725. Available from: 10.2174/1389450117666161207141020

24. Pfeffer CM, Singh AT. Apoptosis: a target for anticancer therapy. International Journal of Molecular Sciences. 2018;19(2):448. PMID: 29393886. Available from: 10.3390/ ijms 19020448 .

25. Singh R, Letai A, Sarosiek K. Regulation of apoptosis in health and disease: the balancing act of BCL-2 family proteins. Nature Reviews Molecular Cell Biology. 2019;20(3):17593. PMID: 30655609. Available from: 10.1038/s41580-018$0089-8$.

26. Cheng $X$, Ferrell JE. Apoptosis propagates through the cytoplasm as trigger waves. Science. 2018;361(6402):607-12. PMID: 30093599. Available from: 10.1126/science.aah4065.

27. Russo A, Cardile V, Graziano AC, Avola R, Bruno M, Rigano D. Involvement of $\mathrm{Bax}$ and $\mathrm{Bcl}-2$ in induction of apoptosis by essential oils of three Lebanese Salvia species in human prostate cancer cells. International Journal of Molecular Sciences. 2018;19(1):292. PMID: 29351194. Available from: 10.3390/ijms19010292.

28. Khursheed A, Rather MA, Rashid R. Plant-based natural compounds and herbal extracts as promising apoptotic agents: their implications for cancer prevention and treatment. Adv Biomed Pharma. 2016;3(4):245-69. Available from: 10.19046/ abp.v03i04.08.

29. Li X, He S, Ma B. Autophagy and autophagy-related proteins in cancer. Molecular Cancer. 2020;19(1):12. PMID: 31969156. Available from: 10.1186/s12943-020-1138-4.

30. Yun CW, Lee SH. The roles of autophagy in cancer. International Journal of Molecular Sciences. 2018;19(11):3466. PMID: 30400561. Available from: 10.3390/ijms19113466.

31. Ko M, Oh GT, Park J, Kwon HJ. Extract of high hydrostatic pressure-treated danshen (Salvia miltiorrhiza) ameliorates atherosclerosis via autophagy induction. BMB Reports. 2020;53(12):652-7. PMID: 33172543. Available from: 10.5483/ BMBRep.2020.53.12.184.

32. Klaunig JE, Wang Z. Oxidative stress in carcinogenesis. Current Opinion in Toxicology. 2018;7:116-21. Available from: 10.1016/j.cotox.2017.11.014.

33. Kunchithapautham K, Rohrer B. Apoptosis and autophagy in photoreceptors exposed to oxidative stress. Autophagy. 2007;3(5):433-41. PMID: 17471016. Available from: 10.4161/ auto.4294. 
Ready to submit your manuscript? Choose Biomedpress and benefit from:

- Fast, convenient online submission

- Through peer-review by experienced researchers

- Rapid publication on acceptance

- Free of charge (without publication fees)

Learn more http://www.biomedpress.org/journals/
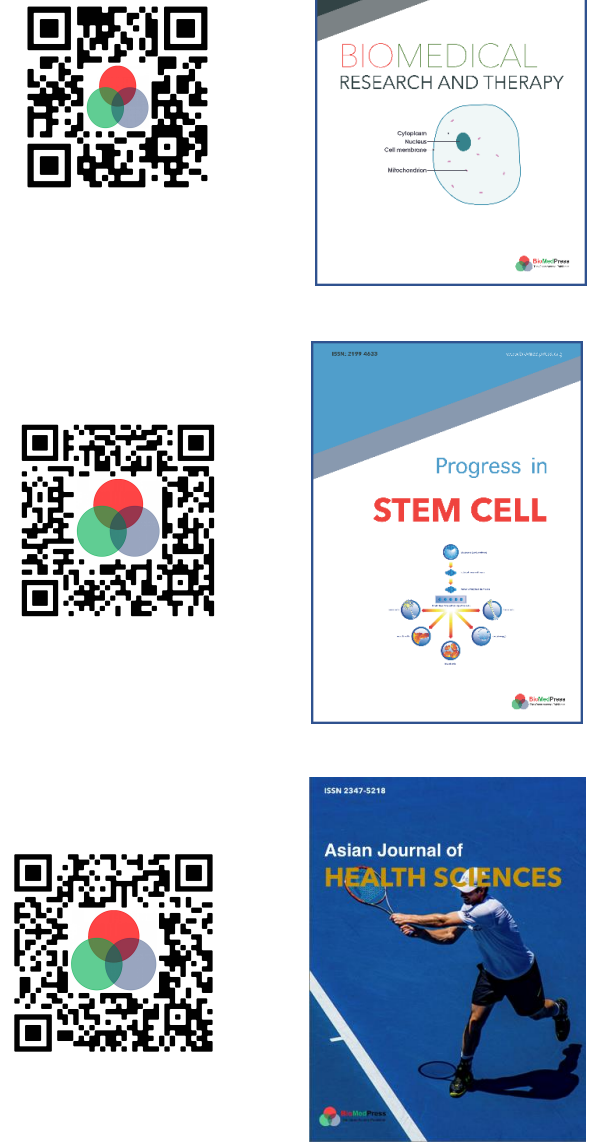

Asian Journal of Health Sciences

ISSN: 2347-5218

Indexed: Google Scholar

Acceptance Rate (2020): 72.89\%

Article Publishing Charge: Free

Submission to first editorial decision: 16.5 days

Biotechnological Research

ISSN: 2395-6763

Indexed: Google Scholar

Acceptance Rate (2020): $67.02 \%$

Article Publishing Charge: Free

Submission to first editorial decision: 28.5 days 